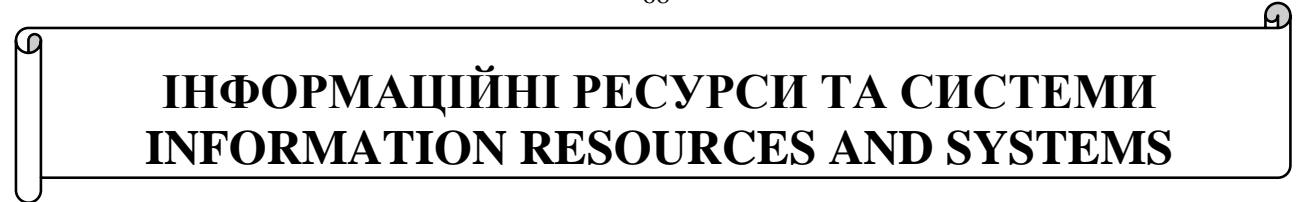

UDC 004.912

Yevheniy B. Shapovalov ${ }^{1}$, Postgraduate student at the Department of Biochemistry and Environmental Control of the National University of Food Technologies, Researcher at the National Center "Junior Academy of Sciences of Ukraine"

ORCID ID 0000-0003-3732-9486 e-mail: Gws0731512025@gmail.com

Viktor B. Shapovalov ${ }^{2}$, Postgraduate student

ORCID ID: 0000-0001-6315-649X e-mail: 2429920@gmail.com

Oleksandr Ye. Stryzhak ${ }^{1}$, D. S. (Engineering), Acting Deputy Director for Science

ORCID ID 0000-0002-4954-3650 e-mail: stryzhak@man.gov.ua

Anatoliy I. Salyuk ${ }^{3}$, Professor at the Department of Food Chemistry

ORCID ID 0000-0003-3949-1962 e-mail: Salyuk2008@gmail.com

${ }^{1}$ National Center "Junior Academy of Sciences of Ukraine", Kyiv, Ukraine

${ }^{2}$ Institute of Telecommunication and Global Information Space of NASU, Kyiv, Ukraine

${ }^{3}$ National University of Food Technologies, Kyiv, Ukraine

\title{
ONTOLOGY BASED SYSTEMAZING OF \\ THE SCIENCE INFORMATION DEVOTED TO WASTE UTILIZING BY METHANOGENESYS
}

\begin{abstract}
Quantity of the scientific materials in the field of biogas production is growing. Thus, it is actual to provide informational management of it. Previously text documents and not-interactive pictures were used to describe it. The approach to systematization of scientific information on the production of biogas based on the ontological IT platform of TODOS is developed. It is proposed to separate the semantic characteristics of each work for their further introduction it into the IT platform of the TODOS. To construct a system of ranking of previous studies, we have identified the semantic characteristics of scientific research devoted to the production of biogas from chicken manure. Temperature $\left({ }^{\circ} \mathrm{C}\right)$, volume of reactor $(l)$, chicken manure content (\%), moisture content (\%), active sludge content (\%), final solids content (\%), biogas production and methane ( $\mathrm{ml} / \mathrm{g} T S)$, methane content (\%), year of the research, ammonium nitrogen content $(\mathrm{mg} / \mathrm{l}), V F A(\mathrm{mg} / \mathrm{l}), \mathrm{pH}$ is final, initial $\mathrm{pH}$, minimum $\mathrm{pH}$, maximum $\mathrm{pH}$ were used to create ontology management system of the previous researches devoted to biogas production. The characteristics of the microorganisms were used to create the ontology based system of the microorganism selection. Google sheets was used to create base of knowledge and previous researches. An ontological graph with a ranking function for previous
\end{abstract}

(C) Ye.B. Shapovalov, V.B. Shapovalov, O.Ye. Stryzhak, A.I. Salyuk, 2018 
scientific research and a system of selection of microorganisms has been developed. Thus, the proposed systems allow to systematize previous research and theoretical information devoted to help of ontological graphs and provide information management in this field. Developed approaches allow us to analyze the results of previous research and theoretical information which provides systemizing of information and information management in general.

Keywords: biogas information; ontology; information management; TODOS; systematization

\title{
С.Б. Шаповалов ${ }^{1}$, В.Б. Шаповалов ${ }^{2}$, О.С. Стрижак ${ }^{1}$, А.І. Салюк ${ }^{3}$ \\ ${ }^{1}$ Національний центр “Мала академія наук України”, м. Київ, Україна \\ ${ }^{2}$ Інститут телекомунікацій і глобального інформаційного простору, м. Київ, Україна \\ ${ }^{3}$ Національний університет харчових технологій, м. Київ, Україна
}

\section{ВИКОРИСТАННЯ ОНТОЛОГІЧНИХ ІНСТРУМЕНТІВ ДЛЯ СИСТЕМАТИЗАЦІЇ ТА АНАЛІЗУ ІНФОРМАЦЇ̈ ЩОДО УТИЛІЗАЦІЇ ВІДХОДІВ ШЛЯХОМ МЕТАНОГЕНЕЗУ}

\begin{abstract}
Анотація. Розроблено підхід до систематизації наукової інформації щцодо виробництва біогазу на базі онтологічної ІТ-платформи ТОДОС. Запропоновано визначати семантичні характеристики кожної роботи для їх подальшого внесення до IT-платформи ТОДОС. Розроблено онтологічний граф з функиією ранжування для попередніх наукових досліджень та системи добору мікроорганізмів. Реалізачія онтологічного підходу до аналізу наукової інформації забезпечує високий рівень інформачійного менеджменту науковими дослідженнями.
\end{abstract}

Ключові слова: біогаз; онтологія; інформачійний менеджмент; ТОДОС; систематизація

\section{Вступ}

Протягом останніх десятиліть кількісний обсяг наукової інформації, що розробляється та отримано у процесі наукових досліджень, стрімко зростає, а iii аналіз стає все більш складним та ресурсозатратним.

Спостерігається тенденція до зростання кількості наукових публікацій та патентів, присвячених виробництву біогазу, причому ріст, починаючи з 2000 року, є експоненційним. Так, кількість патентів, присвячених виробництву біогазу, у 2000 році була близькою до 70, а у 2017 році становила 2235 (рис. 1). Кількість статей також характеризувалась подібною тенденцією: у 2000 році була близькою до 50, а 2017 року становила 3,959 (рис. 2) [8].

Окрім того, існує досить велика кількість несистематизованих даних, які необхідно використовувати при біотехнологічних дослідженнях. Враховуючи, що інформація накопичується, пї науково-аналітичне оброблення 3 кожним роком ставатиме все складнішим, а отже, постає проблема щодо інформаційного менеджменту наукової галузі, зокрема, щодо виробництва біогазу. 


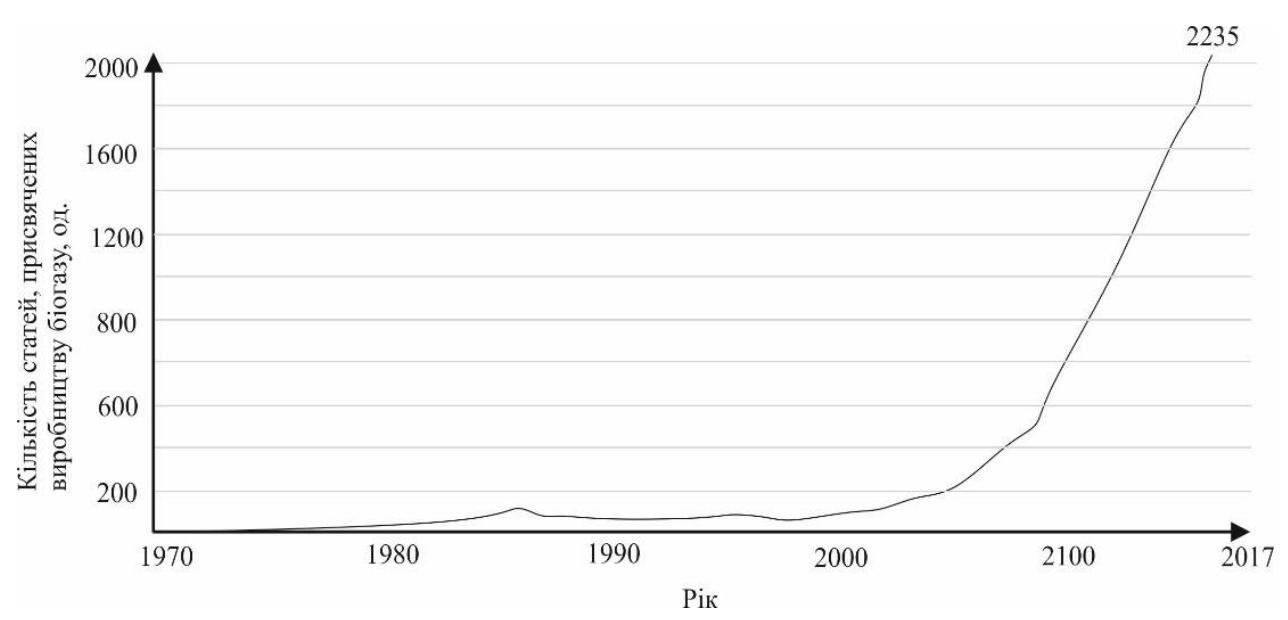

Рис. 1 - Кількість патентів, присвячених виробництву біогазу [8]

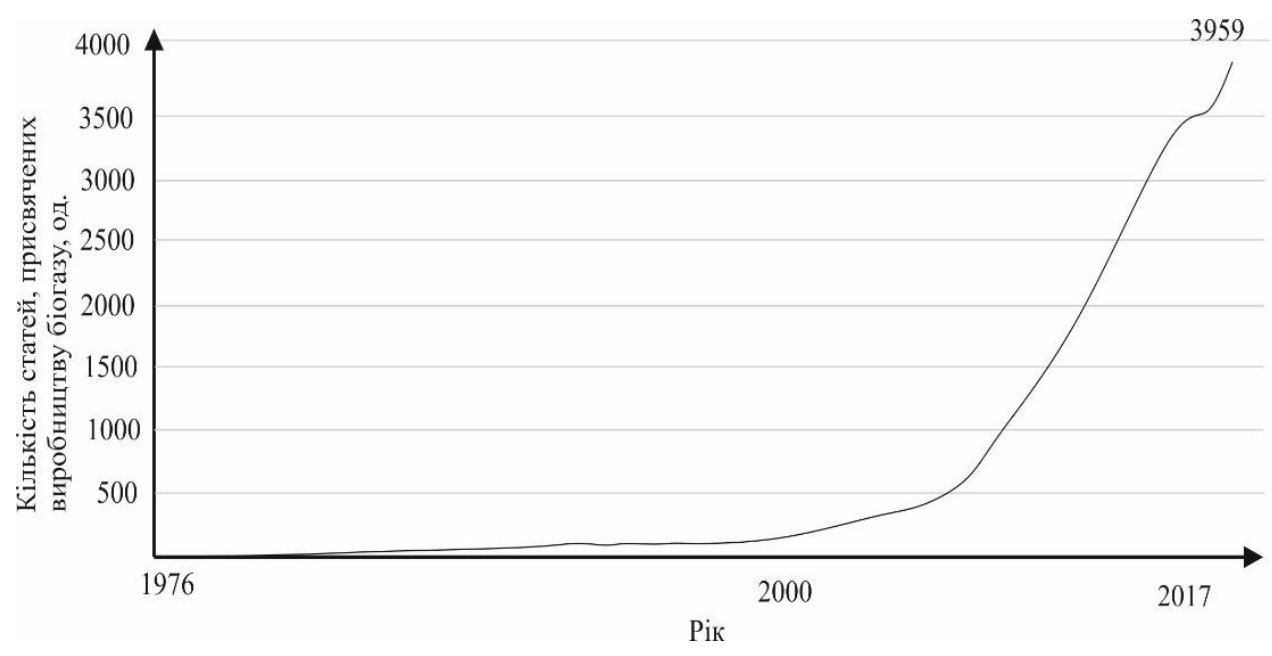

Рис. 2 - Кількість статей, присвячених виробництву біогазу [8]

Мета роботи: запропонувати підхід до систематизації інформації щодо виробництва біогазу для проведення наукової роботи.

\section{Літературний огляд}

На даний момент застосовуються інструменти, які не дозволяють проводити глибинний семантичний аналіз літературних даних, а дають змогу лише отримувати результати, що релевантні за запитом користувача. Для цього зазвичай використовують індексатор Google i запити до безлічі існуючих наукометричних баз даних типу Google scholar, Microsoft Academy, Scopus $[7,9,10]$.

Недоліком використання таких систем $є$ відсутність інформаційного менеджменту. Зокрема, актуальнј. $є$ розробка систем, що дозволяють оперативно підібрати наукову роботу, 3 якою необхідно ознайомитись досліднику. Одним з якісних шляхів вирішення вказаної проблеми є ранжування наукових результатів за характеристиками, які $є$ важливими для дослідника. 
Технологічну платформу, яка забезпечує операціональність виконання вказаної задачі, найбільш ефективно реалізовувати за допомогою сервісів когнітивної ІТ-ТОДОС. Вона дозволяє виділити семантичні характеристики кожної наукової праці, які можуть бути використані у якості критеріїв вибору наукових досліджень [2]. Приклад систем ранжування представлений на рис. 3 та 4.

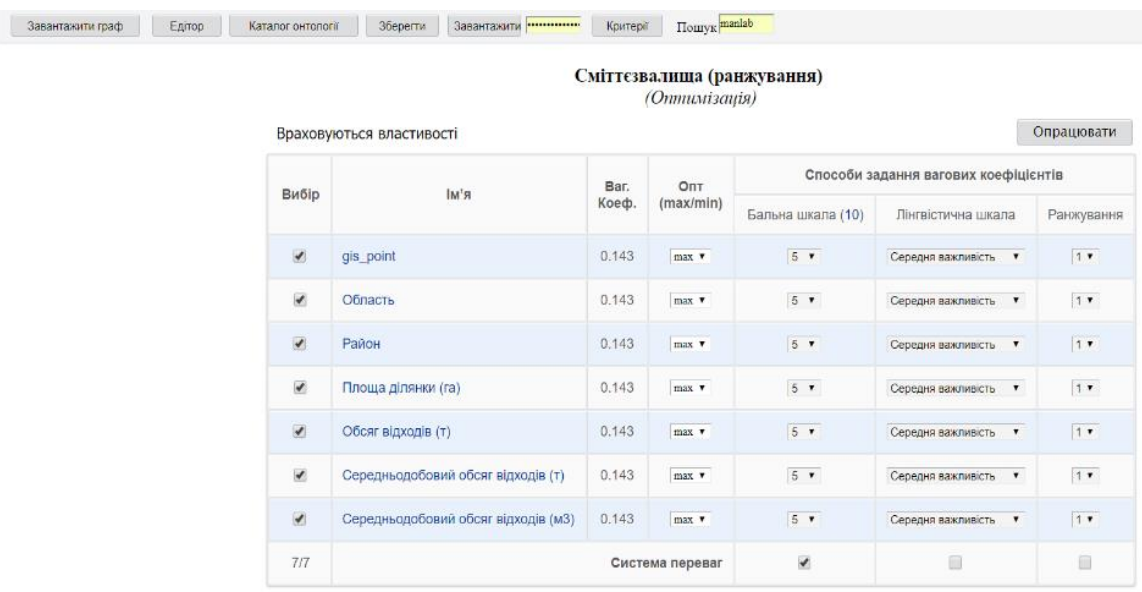

Рис. 3 - Класичний вигляд системи ранжування онтологічних вершин

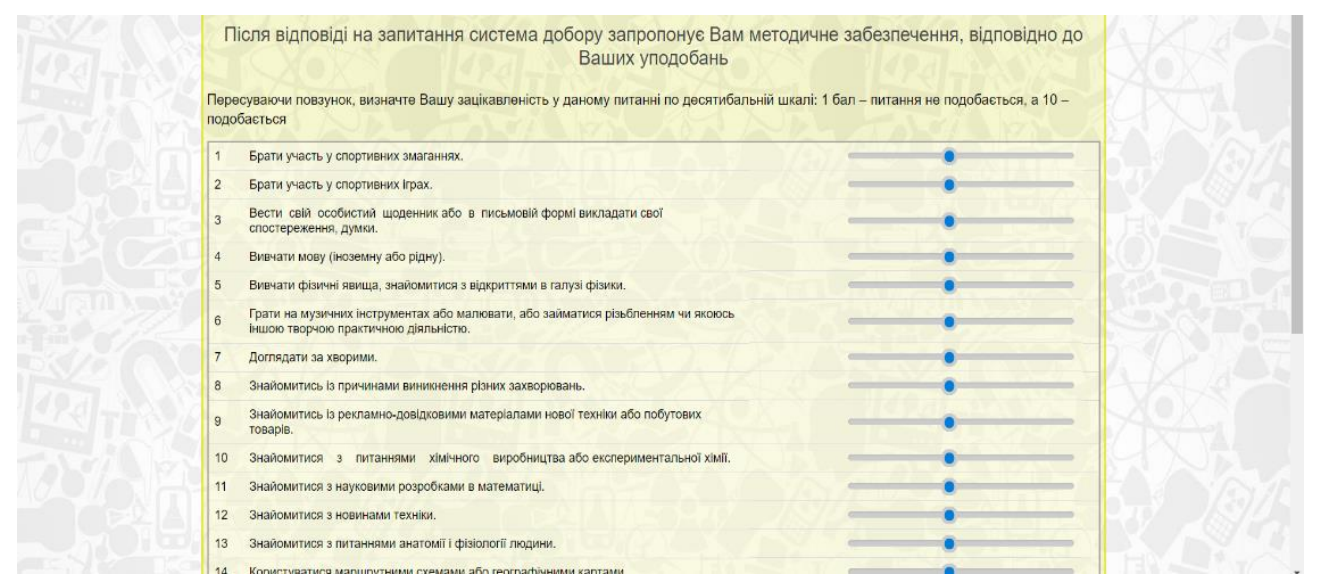

Рис. 4 - Оновлений вигляд системи ранжування результатів

Однак, систематизація наукових даних 3 використанням ранжування семантичних характеристик попередніх напрацювань у галузі біотехнологічних досліджень на сьогодні не була реалізованою. Тому науковою задачею $\epsilon$ адаптація платформи, здатної ранжувати дані за значеннями семантичних характеристик, для використання iii 3 метою систематизації попередніх досліджень. Даний підхід можливо реалізувати за умови, якщо цифрові характеристики мають кількісні значення.

Досить часто для дослідження необхідно використовувати теоретичну інформацію, що не має числових виразів. Прикладом такого теоретичного матеріалу $\epsilon$ класифікація мікроорганізмів. Однак, на даний момент 
класифікація мікроорганізмів представлена у вигляді схем та ієрархій, які не дозволяють швидко та оперативно працювати 3 інформацією. Операціональність використання таких ієрархій суттєво підвищується на основі їх перетворення у таксономічний вигляд [6]. Приклад підходу до відображення систематизації таксономій мікроорганізмів показаний на рис. 5.

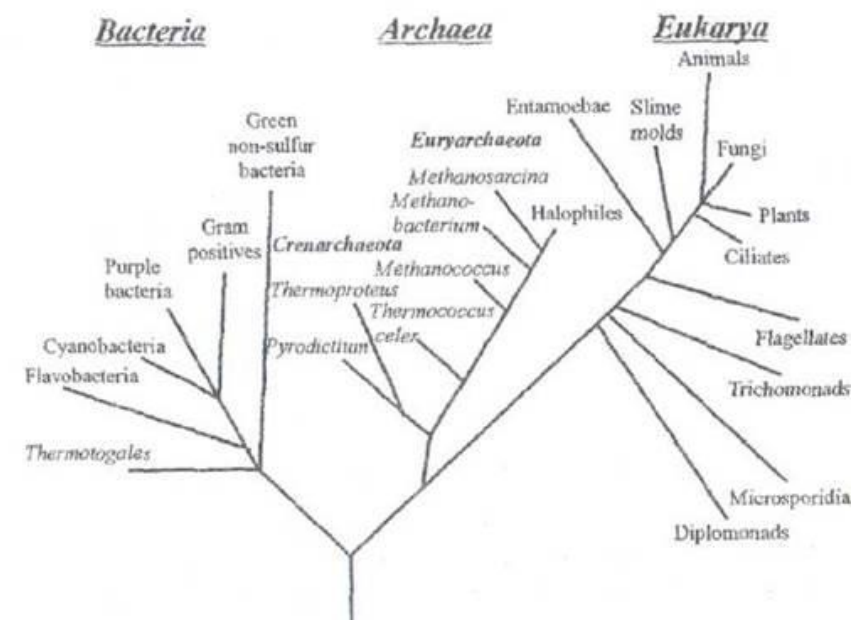

Рис. 5 - Приклад підходу до відображення систематизації таксономій мікроорганізмів

Для інформаційного менеджменту інформації про мікроорганізми запропоновано використовувати інструмент фільтрування, який реалізовано у середовищі ІТ-платформи ТОДОС. Частково дана функція вже реалізована попередньо, однак вперше запропоновано використовувати іiі як спосіб систематизованого відображення інформації при проведенні наукових робіт $[1,4,5]$. Функція фільтрування IT-платформи ТОДОС на прикладі системи підбору біотехнологій для очистки води представлена на рис. 6.

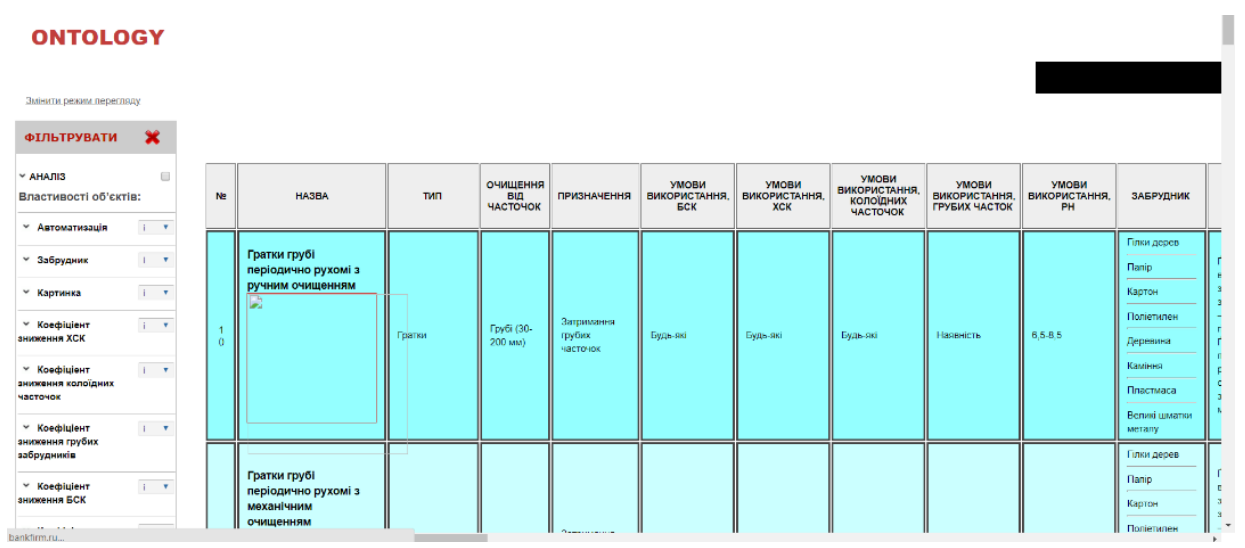

Рис. 6 - Приклад фільтрування підходів екологічної біотехнології з використанням фільтрування відображень

Особливості роботи інструментів фільтрування та ранжування представлені у наших попередніх роботах $[1,4,5]$. 


\section{Матеріали і методи досліджень}

Зберігання інформації здійснювалось 3 використанням google таблиць для забезпечення сумісного доступу та подальшої їх конвертації у таблиці Excel формату xls та csv. Отримані документи використовувались для створення структури онтології (xls) та наповнення онтологічних графів ранжування та фільтрування. Для цього вони завантажувались у editor4, що є складовою IT-платформи ТОДОС. Після чого здійснювалась генерація графу та внесення семантичних характеристик до кожної вершини. Отримані онтологічні графи відкривались у відповідному вигляді, ранжування або фільтрування.

\section{Результати і обговорення}

Для побудови системи ранжування попередніх досліджень нами виділено семантичні характеристики наукових досліджень, присвячених виробництву біогазу з курячого посліду. До таких семантичних характеристик віднесено температуру $\left({ }^{\circ} \mathrm{C}\right)$, об'єм реактору (л), вміст курячого посліду $(\%)$, вміст вологи $(\%)$, вміст активного мулу (\%), кінцевий вміст сухих речовин (\%), виробництво біогазу та метану (мЛ/Г СОР), вміст метану (\%), рік, вміст амонійного Нітрогену (мг/л), ЛЖК (мг/л), $\mathrm{pH}$ кінцеве, $\mathrm{pH}$ початкове, $\mathrm{pH}$ мінімальне, $\mathrm{pH}$ максимальне [3].

Дані семантичні характеристики були виділені з досліджень, що стосуються твердофазної ферментації, та внесені у google таблиці (рис. 7).

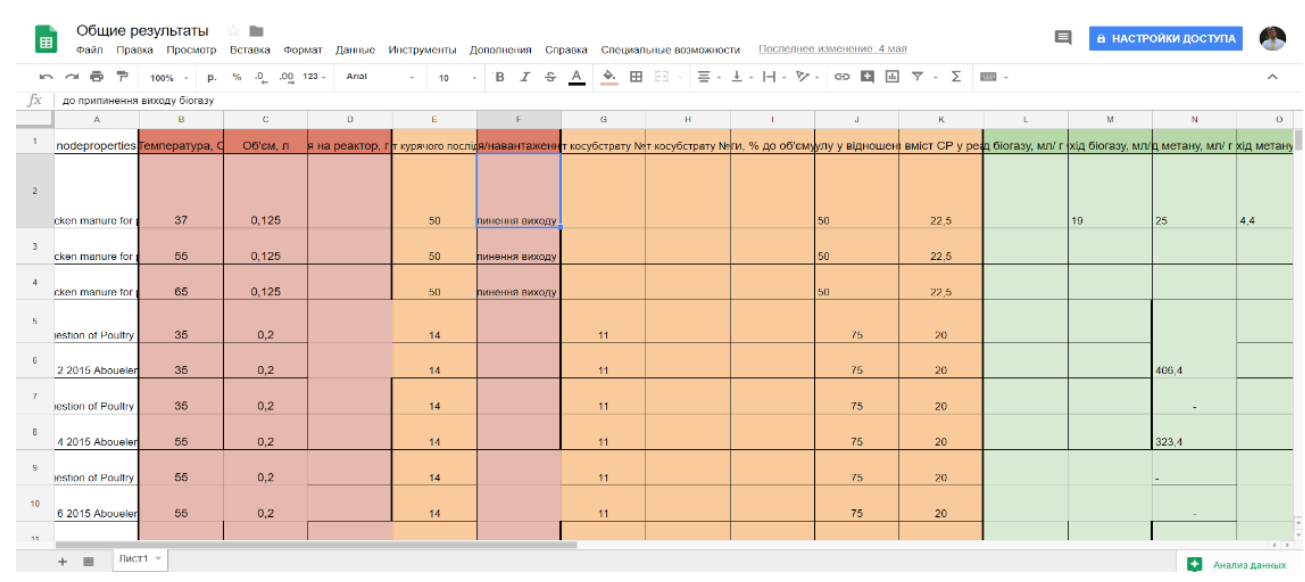

Рис. 7 - Загальний вигляд вкладного файлу для системи ранжування результатів літературного огляду

Дані таблиці за методами, описаними у наших попередніх статтях $[1,4,5]$, внесені до ІТ-платформи ТОДОС. Внаслідок цього стало можливим застосувати ранжування до наукових результатів. Загальний вигляд онтології представлений на рис. 8. Інтерфейс вибору важливості показників представлений на рис. 9, а інтерфейс ранжування результатів - на рис. 10. 


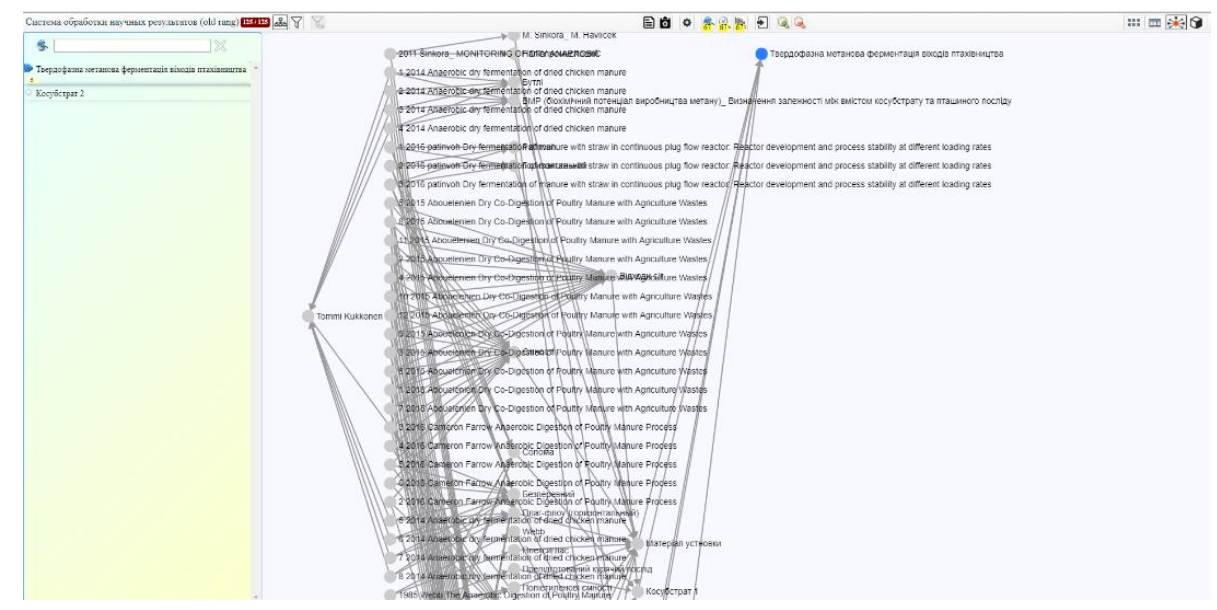

Рис. 8 - Загальний вигляд онтології попередніх досліджень

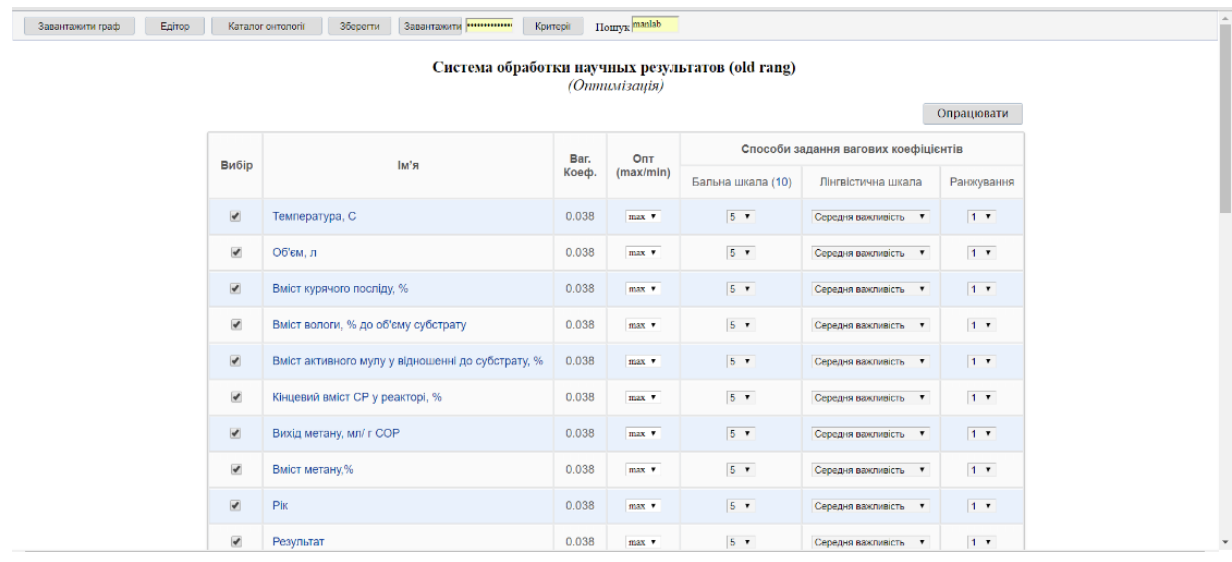

Рис. 9 - Інтерфейс вибору важливості показників

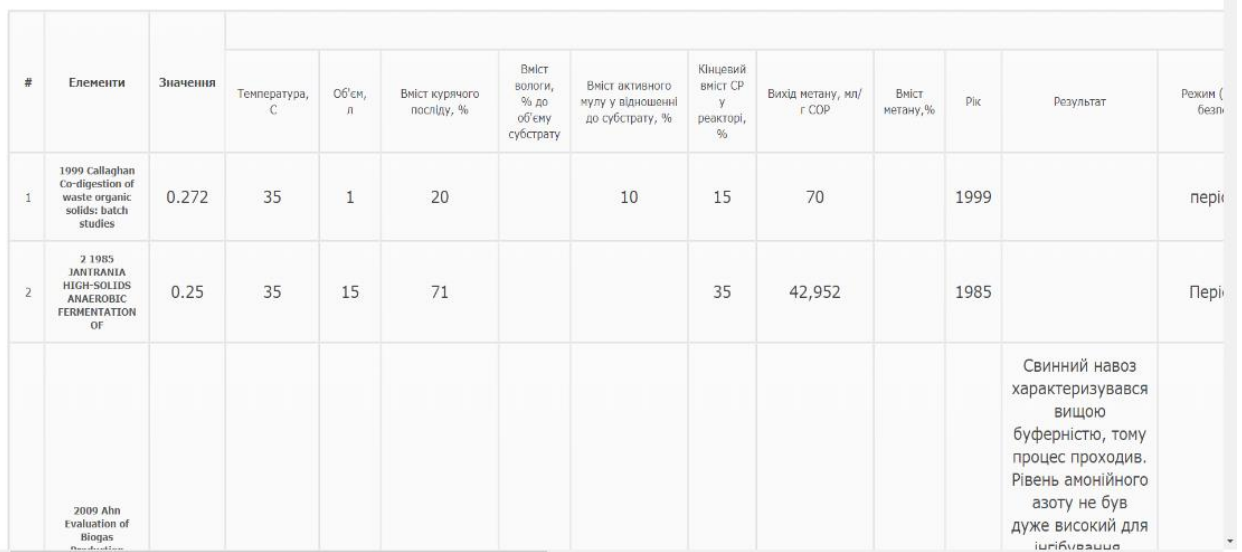

Рис. 10 - Інтерфейс ранжування наукових результатів

Інтерфейс вибору пріоритетів семантичних характеристик для ранжування дозволяє враховувати пріоритетність сучасних статей, при правильному 
розставленні критеріїв важливості. Розглянута система дозволяє швидко відсортувати інформацію за необхідним критерієм.

Систематизація знань в галузі біотехнології також може бути ускладнена у зв'язку з тим, що семантичні характеристики не завжди можуть мати кількісне вираження, а отже, система ранжування не завжди може вирішити питання інформаційного менеджменту.

Для таких систем запропоновано виділяти семантичні характеристики та застосовувати функцію фільтрування. Для цього також були запропоновані семантичні характеристики кожного мікроорганізму та внесені у google таблиці. Семантичні характеристики вносились у режимі колективного доступу. Загальний вигляд вкладного файлу для системи добору мікроорганізмів представлено на рис. 11.

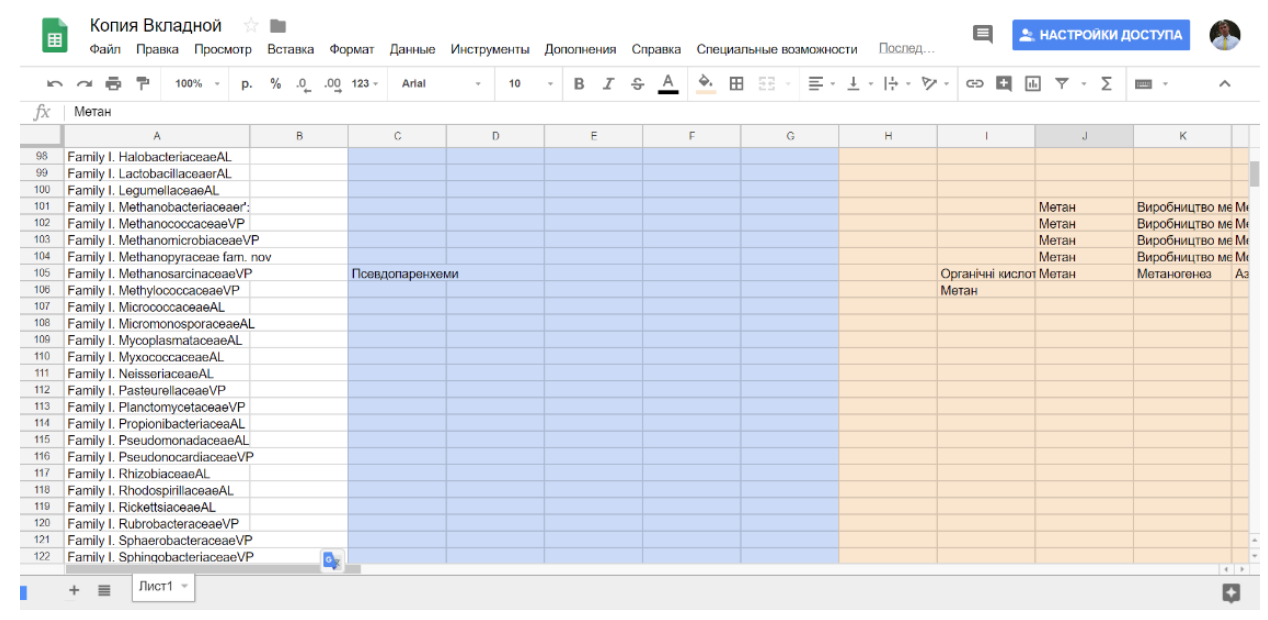

Рис. 11 - Загальний вигляд вкладного файлу для системи добору мікроорганізмів

Отриманий онтологічний граф надає можливість використання функції фільтрування, а відповідно, можливо добрати досліджуваний мікроорганізм або групу мікроорганізмів. Загальний вигляд онтологічної таксономії мікроорганізмів представлений на рис. 12, а загальний вигляд системи добору мікроорганізмів - на рис. 13.
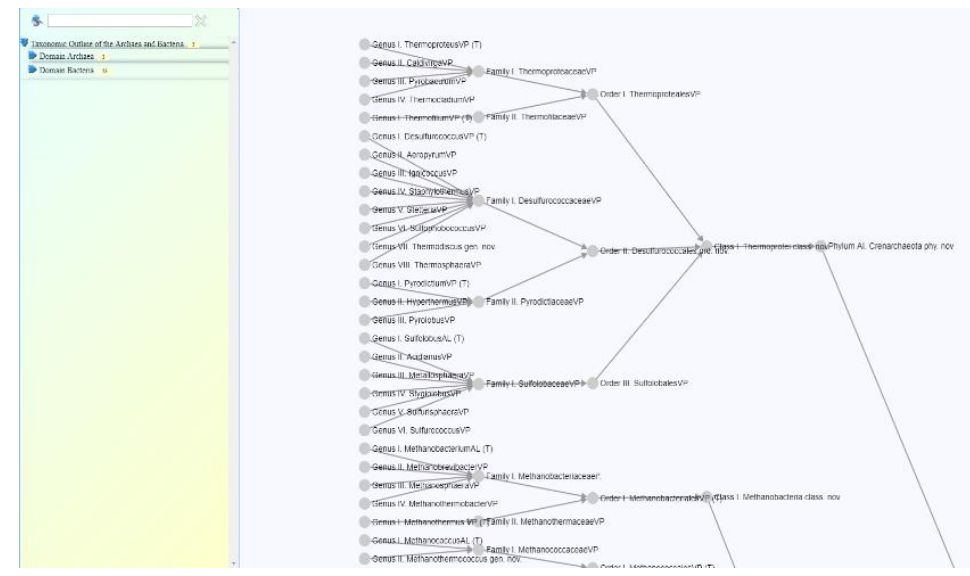

Рис. 12 - Загальний вигляд онтологічної таксономії мікроорганізмів 


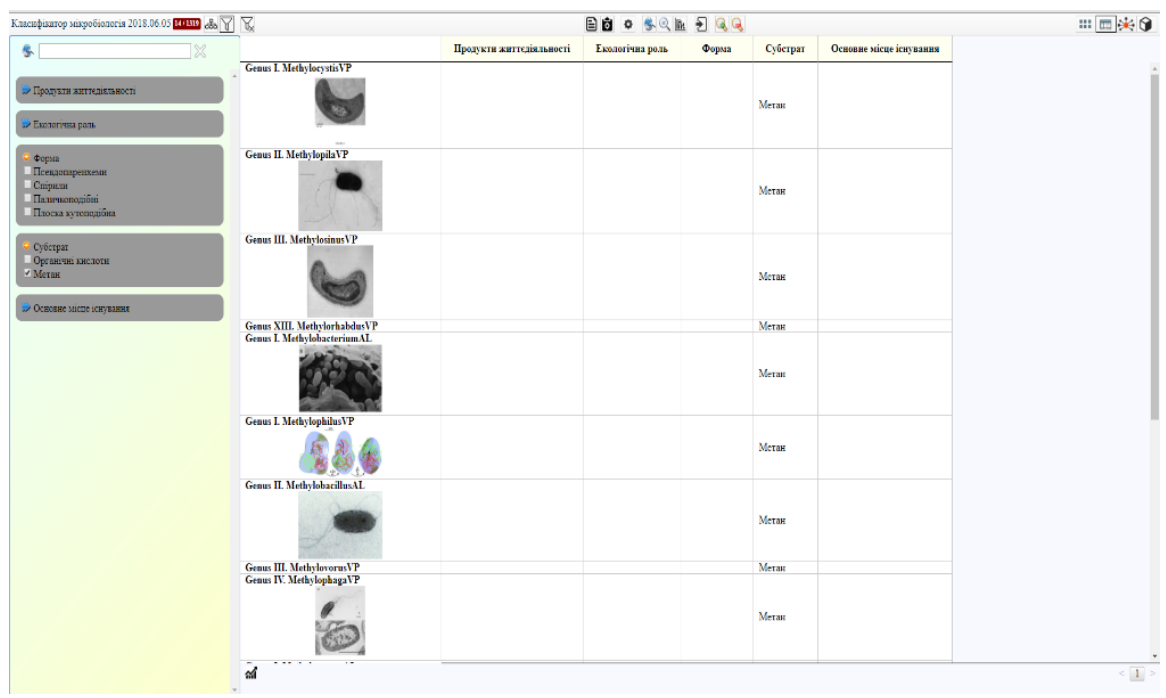

Рис. 13 - Загальний вигляд системи добору мікроорганізмів

\section{Висновки}

Таким чином, запропоновані системи дозволяють систематизувати попередні дослідження та теоретичну інформацію за допомогою онтологічних графів та забезпечити інформаційний менеджмент у даній сфері. Розроблені підходи дозволяють аналізувати результати попередніх досліджень та теоретичну інформацію, а також оперативно працювати з даною інформацією.

\section{СПИСОК ЛІТЕРАТУРИ}

1. Використання інформаційних інструментів для структуризації та візуалізації наукових знань при проведенні попереднього дослідження / I.C. Чернецький, Є.Ю. Пащенко, А.І. Атамась, С.Б. Шаповалов. // Наукові записки Малої академії наук України : зб. наук. праць. Вип. 7 / Національний центр «Мала академія наук України»; [редкол. : С.О. Довгий (голова), О.Є. Стрижак, І.М. Савченко (відп. ред.) та ін.]. - К. : Інститут обдарованої дитини НАПН України, 2016. - (Серія: Педагогічні науки, вип. 7), С. 20-28.

2. Величко В.Ю. ТОДОС - IT-платформа формування трансдисциплінарних інформаційних середовищ / В.Ю. Величко, М.А. Попова, В.В. Приходнюк, О.Є. Стрижак. - Системи озброєння і військова техніка, 2017. - Вип. 1(49). - С. 10-19. 3. Влияние водопотребления на эффективность метанового брожения куриного помета / А.И. Салюк, С.А. Жадан, Е.Б. Шаповалов, Р.А. Тарасенко. // International Scientific Journal for Alternative Energy and Ecology (ISJAEE). - 2015. - №15-16. - C. 53-58.

4. Доцільність створення систем онтологічного аналізу для інтеграції наукових знань / I.C. Чернецький, Є.Ю. Пащенко, Є.Б. Шаповалов, В.Б. Шаповалов. Сучасні проблеми математичного моделювання, прогнозування та оптимізації, збірник статей м. Кам'янець-Подільський. - К.-П.: Кам'янець-Подільський національний університет імені Івана Огієнка. - 2016 - С. 75-84.

5. Інформаційні онтологічні інструменти для забезпечення дослідницького підходу в STEM-навчанні / В. Б. Шаповалов, Є. Б. Шаповалов, А. І. Атамась, Ж. І. Білик. // Обдаровані діти - інтелектуальний потенціал держави матеріали Х Міжнародної науково-практичної конференції 3-10 липня 2017 року м. Чорноморськ, Одеська область. -2017. - С. 366-371. 
6. Шаталкин, А.И. Таксономия. Основания, принципы и правила [Текст] / А.И. Шаталкин. - М. : Товарищество научных изданий КМК, 2012. - 600 с.

7. Стрижак О.Е. Трансдисциплінарна інтеграція інформаційних ресурсів // Автореферат дисертації на здобуття наукового ступеня доктора технічних наук. - К. Інститут телекомунікацій і глобального інформаційного простору НАН України. 2015. $-42 \mathrm{c}$.

8. Google Scholar [Електронний ресурс] // Google - Режим доступу до ресурсу: https://scholar.google.com/

9. Lens.org [Електронний ресурс] - Режим доступу до ресурсу: https://www.lens.org 10. Microsoft Academic [Електронний ресурс] // Microsoft - Режим доступу до ресурсу: https://academic.microsoft.com/

11.Scopus [Електронний ресурс] - Режим доступу до ресурсу: https://www.scopus.com/home.uri

Стаття надійшла до редакції 22.08.2018

\section{REFERENCES (TRANSLATED AND TRANSLITERATED)}

1. Chernec'kyj, I. S., Pashhenko, Y. Y., Atamas', A. I., \& Shapovalov, Ye. B. (2016). Vykorystannja informacijnyh instrumentiv dlja strukturyzacii' ta vizualizacii' naukovyh znan' pry provedenni poperedn'ogo doslidzhennja. Scientific Notes [National Center "Junior Academy of Sciences of Ukraine]. Series: Pedagogical Sciences, (7), 20-28 (in Ukrainian).

2. Velychko, V. J., Popova, M. A., Pryhodnjuk, V. V., \& Stryzhak, O. J. (2017). TODOS IT-platforma formuvannja transdyscyplinarnyh informacijnyh seredovyshh. Systemy Ozbrojennja I Vijs'kova Tehnika, 49(1), 10-19 (in Ukrainian).

3. Saljuk, A. I., Zhadan, S. A., Shapovalov, Y. B., \& Tarasenko, R. A. (2015). Vlijanie vodopotreblenija na jeffektivnost' metanovogo brozhenija kurinogo pometa. International Scientific Journal for Alternative Energy and Ecology (ISJAEE), (15-16), 53-58.

4. Chernec'kyj, I. S., Pashhenko, Y. Y., Shapovalov, Y. B., \& Shapovalov, V. B. (2016). Docil'nist' stvorennja system ontologichnogo analizu dlja integracii' naukovyh znan'. Suchasni Problemy Matematychnogo Modeljuvannja, Prognozuvannja Ta Optymizacii', 75-84 (in Ukrainian).

5. Shapovalov, V. B., Shapovalov, Ye. B., Atamas', A. I., \& Bilyk, Z. I. (2017). Informacijni ontologichni instrumenty dlja zabezpechennja doslidnyc'kogo pidhodu v STEM-navchanni. In X Mizhnarodna naukovo-praktychna konferencija «Obdarovani Dity - Intelektual'nyj Potencial Derzhavy» (pp. 366-371). Chornomors'k (in Ukrainian).

6. Shatalkin, A. I. (2012). Taksonomija. Osnovanija, principy i pravila. Moskow: Tovarishhestvo nauchnyh izdanij KMK (in Russian).

7. Stryzhak, O. E. (2015). Transdyscyplinarna integracija informacijnyh resursiv (Doctoral dissertation, Institute of Telecommunication and Global Information Space of NASU) [Abstract]. Kyiv (in Ukrainian).

8. Google Scholar (n.d.). Retrieved from https://scholar.google.com/

9. Lens.org (n.d.). Retrieved from https://www.lens.org

10. Microsoft Academic (n.d.). Retrieved from https://academic.microsoft.com/

11. Scopus (n.d.). Retrieved from https://www.scopus.com/home.uri

Text of the article was accepted by Editorial Team 22.08.2018

\section{Шаповалов Евгеній Борисович}

аспірант кафедри Екологічного контролю Національного університету харчових технологій; науковий співробітник відділу створення навчально-тематичних систем знань НЦ «Мала академія наук України»

Адреса робоча: 04119 Україна, м. Київ, вул. Дегтярівська, 38/44

ORCID ID 0000-0003-3732-9486 e-mail: Gws0731512025@gmail.com 


\section{Шаповалов Віктор Борисович}

аспірант Інституту телекомунікацій і глобального інформаційного простору Адреса робоча: 03186 Україна, м. Київ, Чоколівський бульвар, 13

ORCID ID: 0000-0001-6315-649X e-mail: 2429920@gmail.com

\section{Стрижак Олександр Євгенович}

доктор технічних наук, заступник директора з наукової роботи Національного центру «Мала академія наук України»

Адреса робоча: 04119 Україна, м. Київ, вул. Дегтярівська, 38/44

ORCID ID 0000-0002-4954-3650e-mail: stryzhak@man.gov.ua

\section{Салюк Анатолій Іванович}

професор кафедри харчової хімії Національного університету харчових технологій Адреса робоча: 01033 Україна, м. Київ, вул. Володимирська, 68

ORCID ID 0000-0003-3949-1962 e-mail: Salyuk2008@gmail.com 